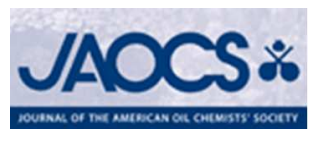

\title{
Effects of High Intensity Ultrasound Frequency and High- Speed Agitation on Fat Crystallization
}

\begin{tabular}{|r|l|}
\hline Journal: & Journal of the American Oil Chemists Society \\
\hline Manuscript ID & JAOCS-17-0153.R1 \\
\hline Manuscript Type: & Original Article \\
\hline Date Submitted by the Author: & n/a \\
\hline Complete List of Authors: & $\begin{array}{l}\text { Silva, Roberta } \\
\text { Lee, Juhee } \\
\text { Martini, Silvana; Utah State University, Department of Nutrition and Food } \\
\text { Sciences }\end{array}$ \\
\hline Keywords: & $\begin{array}{l}\text { Structure - Functional Properties < Food and Feed Science / Nutrition and } \\
\text { Health, Fat crystallization < Lipid Chemistry / Lipid Analysis, Rheology < } \\
\text { Lipid Chemistry / Lipid Analysis, Thermal Analysis < Lipid Chemistry / Lipid } \\
\text { Analysis, Fats and oils }\end{array}$ \\
\hline
\end{tabular}


1 Effects of High Intensity Ultrasound Frequency and High-Speed Agitation on Fat 2 Crystallization

3 R.C. Silva ${ }^{1}$, J. Lee $^{1}$, V. Gibon ${ }^{2}$, and S. Martini ${ }^{1 *}$

$4{ }^{1}$ Department of Nutrition, Dietetics, and Food Science, Utah State University, 8700 Old Main $5 \quad$ Hill, Logan, UT 84322-8700

$6 \quad{ }^{2}$ Desmet Ballestra R\&D Center, Desmet Ballestra Group, Zaventem, Belgium

7

8 *Corresponding author: Silvana Martini, Professor, Department of Nutrition, Dietetics, and 9 Food Sciences, Utah State University, 8700 Old Main Hill, Logan, UT, 84322-8700, 10 silvana.martini@usu.edu, 435-797-8136 
13 Abstract: The objective of this research was to examine the effect of ultrasound frequency 14 and high-speed agitation on lipid crystallization. Interesterified soybean oil was crystallized 15 at $44{ }^{\circ} \mathrm{C}$ without and with the application of high intensity ultrasound (HIU -20 and $40 \mathrm{kHz}$ ) 16 or with high-speed agitation $(6,000$ and $24,000 \mathrm{rpm})$. Two tip amplitudes (24 $\mu \mathrm{m}$ and 108 $17 \mu \mathrm{m})$ and three pulse durations were evaluated $(5,10$, and $15 \mathrm{~s})$ for the acoustic frequencies 18 tested. Sonication at $20 \mathrm{kHz}$ of frequency significantly reduced crystal size, increased ( $<<$ $190.05)$ elasticity $(435.9 \pm 173.3 \mathrm{~Pa}$ to $80,218 \pm 15,384 \mathrm{~Pa})$ and $\mathrm{SFC}(0.2 \pm 0.0 \%$ to $4.5 \pm 0.4$ $20 \%$ ). No significant difference was observed in the crystallization behavior of these samples 21 when sonicated at different amplitudes for 5 and $10 \mathrm{~s}$. The crystallization behavior was 22 significantly delayed $(\mathrm{p}<0.05)$ in samples sonicated using $108 \mu \mathrm{m}$ amplitude for $15 \mathrm{~s}$. 23 Larger crystals were formed in samples sonicated at $40 \mathrm{kHz}$ compared to those obtained with $2420 \mathrm{kHz}$ and lower SFC $(3.7 \pm 0.0 \%)$ and elasticity $(3,943 \pm 1,459 \mathrm{~Pa})$ values were obtained. 25 High-speed agitation at 24,000 rpm increased SFC (5.5 $\pm 0.1 \%)$ and crystallized area and 26 decreased the elasticity $(42,602 \pm 11,775 \mathrm{~Pa})$ compared to the samples sonicated at $20 \mathrm{kHz}$.

27 Keywords: Interesterified oil, crystallization behavior, sonication, ultrasound, high 28 speed agitation 
29

30

31

32

33

34

35

36

37

38

51 induction in crystallization, generation of smaller and more uniform crystal sizes, induction 52 of stable polymorphic forms, and generation of harder materials. The mechanisms 
53 responsible for sonocrystallization in lipids have not been totally clarified. Some researchers 54 believe that sonocrystallization occurs through an induction in nucleation since cavities or 55 bubbles provide a heterogeneous surface for nucleation [26]. However, others argue that the 56 effect is counterintuitive in that a local temperature increase will reduce or eliminate the 57 supersaturation in the immediate vicinity effectively removing the driving force for 58 nucleation. However, shock waves generated during sonication may contribute to nucleation 59 in the regions of the supersaturated solution somewhat remote from the cavitation event [2]. 60 In the case of lipid sonocrystallization, localized high pressures generated during sonication 61 might result in localized increase in supercooling thus inducing crystallization. Changes 62 observed in crystal size and morphology can be related to the shear forces associated with 63 ultrasound that act to slow growth processes [27] and to break down nascent agglomerates $64 \quad[28]$.

65 Most of ultrasound studies in fat systems have evaluated the effects of ultrasound 66 power levels and pulse duration $[15,18,19,25]$, moreover these previous studies were 67 limited to a single frequency $(20 \mathrm{kHz})$. It is still unclear if the same induction in 68 crystallization can be generated with a higher acoustic frequency and if the effects observed 69 during lipid sonocrystallization are due to the presence of cavities, high shear forces, or a 70 combination of both events. Therefore, the objective of this study is to: (i) evaluate the effect 71 of acoustic frequency on sonocrystallization and (ii) understand the role of agitation in the 72 sonication process. With this purpose commercial interesterified soybean oil ( $45 \%$ saturated 73 fat) was crystallized at $44{ }^{\circ} \mathrm{C}$ and treated with two acoustic frequencies $(20$ and $40 \mathrm{kHz})$ and 74 with high-speed agitation. The physical properties such as crystal microstructure, melting 75 behavior, solid fat content, and elasticity, of the crystallized material obtained were 76 measured. 
77 Material and Methods

78 Material

79 Commercial interesterified soybean oil (IESBO) with 45\% saturated fat (ADM 80 762420) was crystallized at $44{ }^{\circ} \mathrm{C}$ without and with the application of high intensity 81 ultrasound (HIU) or with high-speed agitation.

\section{Methods}

\section{Melting Point}

The melting point of IESBO $(52.8 \pm 0.1)$ was determined by DSC using a DSC Q20

85 (TA Instruments, New Castle, DE). The samples were heated from $25{ }^{\circ} \mathrm{C}$ to $80{ }^{\circ} \mathrm{C}$ at $5{ }^{\circ} \mathrm{C} /$

$86 \mathrm{~min}$, holding at this temperature for $30 \mathrm{~min}$ and cooled to $-20^{\circ} \mathrm{C}$ at $5{ }^{\circ} \mathrm{C} / \mathrm{min}$ to crystallize the

87 sample and holding at this temperature for $90 \mathrm{~min}$. After this procedure, the samples were

88 heated again to $80{ }^{\circ} \mathrm{C}$ at $5{ }^{\circ} \mathrm{C} / \mathrm{min}$. Melting temperature was considered as the peak

89 temperature of the highest temperature melting peak.

90 Triacylglycerol (TAG) and diacylglycerol (DAG) composition

91 The TAG composition of IESBO (Table 1) was analyzed by reversed phase high

92 performance liquid chromatography (HPLC) based on the official AOCS method Ce 5b-89.

93 Minor practical adjustments to the flow rate and mobile phase composition was made for

94 optimal performance of the equipment. The analysis was performed on a Waters HPLC

95 system (Zellik, Belgium) equipped with two stainless steel Nova-Pak C18 columns (4 $\mu$ m,

$963.9 \times 150 \mathrm{~mm}$ ) from Waters (Zellik, Belgium). The mobile phase was an isocratic solvent

97 mixture of acetone and acetonitrile $(62.5 / 37.5, \mathrm{v} / \mathrm{v})$ with a flow rate of $1.2 \mathrm{ml} / \mathrm{min}$; the 
98

99

100

101

102

103

104

105

106

107

108

109

110

111

112

injection volume was $20 \mu \mathrm{l}$. The samples were dissolved in methanol/chloroform $(1 / 1, \mathrm{v} / \mathrm{v})$ and a differential refractometer was utilized for the detection. The partition number (PN) also called equivalent carbon number $(\mathrm{ECN})$ is used to predict the elution order. $\mathrm{PN}(\mathrm{ECN})=\mathrm{CN}$ $-2 \mathrm{x} \mathrm{DB}$, where $\mathrm{CN}$ is the total carbon number and $\mathrm{DB}$ is the total number of double bonds on the fatty acids. Peak areas were correlated with the quantities of DAG/TAG in the oil or fat sample. The data were integrated by using the program Empower Pro with a generic Apex Track method for integration. Peak areas below 4000 area counts (equivalent to approximately $0.04 \%$ of the total peak area) were not taken into account.

\section{Crystallization Experiments}

Samples were melted in a microwave oven and then kept in an oven at $80{ }^{\circ} \mathrm{C}$ for 30 min to eliminate crystal history. The melted sample (100 g) was transferred to a doublewalled crystallization cell connected to an external water bath that allowed for temperature control $\left(44^{\circ} \mathrm{C}\right)$. This crystallization device was previously described in Martini et al. [18]. The sample was stirred for $10 \mathrm{~min}$ using a magnetic stirrer $(200 \mathrm{rpm})$ to improve heat transfer. The crystallization behavior of the samples was followed as a function of time for 90 min. Crystal morphology and solid fat content were monitored during crystallization using a polarized light microscope and pulsed nuclear magnetic resonance equipment (p-NMR) at $44{ }^{\circ} \mathrm{C}$, respectively. Physical properties such as melting behavior and viscoelasticity were measured after 90 min of crystallization time at $44^{\circ} \mathrm{C}$.

\section{Ultrasound Application}

HIU was applied to the samples after 45 min when a slight turbidity was observed that indicated the presence of crystals. Previous research in our laboratory has shown that greater induction in crystallization is observed when HIU is applied at the onset of crystallization 
$121[18,24]$. A Misonix Sonicator 3000 (Misonix Inc., Farmingdale, NY, USA) operating at a 122 frequency of $20 \mathrm{kHz}$ and a custom-made Qsonica Sonicator Q500 (Qsonica, Newtown, CT, 123 USA) operating at a frequency of $40 \mathrm{kHz}$ were used to apply the ultrasound pulse. HIU was 124 applied using a 1/2"-diameter tip operating at two tip amplitudes $(24 \mu \mathrm{m}$ and $108 \mu \mathrm{m})$ and at 125 three pulse durations $(5,10$, and $15 \mathrm{~s})$.

\section{Application of High-speed Agitation}

127 Samples were crystallized as described above and high-speed agitation was applied 128 using an Ultraturrax (IKA - Labortechnik, Staufen, Germany) at 45 min into the 129 crystallization process. Two probes were used: (a) small probe (S18N 10g - circumference 130 speed max: $9.8 \mathrm{~m} / \mathrm{s})$ and (b) big probe (S18N - 19g - circumference speed max: $16.6 \mathrm{~m} / \mathrm{s})$. 131 Each probe was used at 2 speeds: (a) 6,000 rpm and (b) 24,000 rpm for $10 \mathrm{~s}$.

132 Measurement of Solid Fat Content (SFC)

133 Samples were kept in the cell until the application of sonication or high-speed agitation 134 and then transferred to p-NMR tubes and a test tube using a 10-ml pipettor. Tubes were kept 135 in a water bath set at crystallization temperature $\left(T_{c}\right)$ of $44{ }^{\circ} \mathrm{C}$. Tubes were tempered at $T_{c}$ in 136 the water bath before the sample was transferred. The crystallization behavior of the samples 137 was followed by measuring SFC. SFC values of samples during crystallization at $44^{\circ} \mathrm{C}$ were 138 measured using a NMR minispec mq 20 analyzer (Bruker, California, USA). SFC was 139 measured as soon as the sample was taken out of the crystallization cell and every 2 min until 140 the end of crystallization (90 $\mathrm{min})$.

\section{Crystallization Kinetics}

142 The SFC vs. time data were fitted to the reparametrized Gompertz model (eq. 1). 


$$
S F C(t)=S F C_{\max }\left(\exp \left\{-e x\left[\mu \times 2.781281 \times\left(\frac{1-x}{z}\right)+1\right]\right\}\right)
$$

144 The parameter $\mathrm{SFC}_{\max }(\%)$ is related to the final SFC, $\mu\left(\% \cdot \mathrm{min}^{-1}\right)$ is related to the maximal 145 growth rate, whereas $\lambda(\mathrm{min})$ is the induction time of crystallization. This equation has been 146 used previously to describe isothermal crystallization of fats [29-31].

\section{Crystal Microstructure}

148 Crystal morphology was recorded during crystallization using a polarized light 149 microscope (PLM-Olympus BX 41 America Inc., Melville, NY, USA) with a digital camera 150 (Lumenera Scientific, Infinity 2, Ottawa, Ontario, Canada) attached and a temperature151 controlled stage (Instec, TS62, Colorado, USA) to allow for temperature control during the 152 measurement. A 20 X magnification objective was used. PLM images were taken every 10 $153 \mathrm{~min}$ throughout the crystallization experiment at $44{ }^{\circ} \mathrm{C}$.

\section{Melting Behavior}

155 The melting behavior of the crystallized material was evaluated using a differential 156 scanning calorimeter (DSC-TA Instruments, New Castle, DE, U.S.A.). The crystallized 157 material $(5-15 \mathrm{mg})$ was placed in a hermetic aluminum pan and heated from $\mathrm{T}_{\mathrm{c}}\left(44^{\circ} \mathrm{C}\right)$ to 80 $158{ }^{\circ} \mathrm{C}$ at $5^{\circ} \mathrm{C} / \mathrm{min}$ to evaluate its melting behavior. Melting parameters such as onset temperature $159\left(\mathrm{~T}_{\mathrm{on}}\right.$; the temperature at which the sample starts melting), peak temperature ( $\mathrm{T}_{\mathrm{p}}$; the 160 temperature at which the melting peak reaches its maximum), and melting enthalpy (energy 161 required for melting) were recorded.

\section{Viscoelastic Properties}


163 A magnetic bearing rheometer (TA Instruments AR-G2, New Castle, DE, USA) was 164 used to evaluate the viscoelastic properties of the material after 90 min of crystallization. A 165 temperature-controlled standard size recessed end concentric cylinders geometry (15.17 166 mm diameter - 991036) was used. The geometry temperature was set at $44{ }^{\circ} \mathrm{C}$ and a gap of $1674000 \mu \mathrm{m}$ was used for these measurements. Oscillatory tests were performed by strain 168 sweep step to obtain viscoelastic parameters such as the storage modulus $\left(G^{\prime}\right)$ from the linear 169 viscoelastic region.

\section{Statistical Analysis}

Crystallization experiments were performed in triplicate and physical properties were 172 measured in triplicate (SFC and crystal microstructure) and duplicate (DSC and elasticity). 173 Significant di $\square$ erences $(\alpha=0.05)$ were evaluated using two-way ANOVA using GraphPad 174 Prism software, version 6.00 for Windows (GraphPad Software, San Diego, CA, USA).

\section{Results and Discussion}

\section{Solid fat content}

Figure 1 shows the crystallization behavior of IESBO measured by SFC as a function 178 of time when di $\square$ erent acoustic amplitudes and pulse duration were used at $20 \mathrm{kHz}$ (Figure 179 1A), $40 \mathrm{kHz}$ (Figure 1B), and high-speed agitation (Figure 1C). The solid fat content after 90 min of crystallization of sonicated and high-speed agitated samples are shown in Table 2.

Figure 1A shows the curves of SFC for non-sonicated IESBO and for sonicated at 20 kHz. Non-sonicated IESBO started crystallizing at $44 \mathrm{~min}$ and SFC did not increase in a 183 significant manner over the $90 \mathrm{~min}$ of crystallization with a final SFC of $0.2 \%$. The SFC of 184 all sonicated samples increased over time in a sigmoidal manner, reaching a plateau 
185 approximately after $75 \mathrm{~min}$ for amplitudes $24 \mu \mathrm{m}$ and $108 \mu \mathrm{m}$ with $10 \mathrm{~s}$ pulse $(3.7 \pm 0.2 \%$ 186 and $3.9 \pm 0.2 \%$ respectively), indicating that an equilibrium of SFC [32] was first established 187 for these samples compared to the ones sonicated using $108 \mu \mathrm{m}$ amplitude for $5 \mathrm{~s}$ that 188 reached the plateau after 83 min of crystallization $(4.3 \pm 0.04 \%)$ and $108 \mu \mathrm{m}$ amplitude for $18915 \mathrm{~min}$ in which the plateau was reached almost at the end of the experiment at $90 \mathrm{~min}(3.7 \pm$ $190 \quad 0.21 \%$ ). SFC values were fitted to the Gompertz equation and all sonicated samples were 191 well fitted with $\mathrm{R}^{2}$ values above 0.91 (Table 3). Non-sonicated samples did not fit the 192 Gompertz equation $\left(\mathrm{R}^{2}=0.71\right)$ since its SFC did not increase as a function of time and 193 remained close to zero. IESBO sonicated with 24 and $108 \mu \mathrm{m}$ for $10 \mathrm{~s}$ had shorter induction 194 times $(51.1 \pm 0.7$ and $50.8 \pm 0.5 \mathrm{~min})$ and a significant $(\mathrm{p}<0.0001)$ greater growth rate $(0.2 \pm$ 1950.0 and $0.2 \pm 0.0 \% \mathrm{~min}^{-1}$ ) when were compared to the other sonication conditions at $20 \mathrm{kHz}$. 196 Results obtained for the same amplitude $(108 \mu \mathrm{m})$ suggest that pulse duration plays an 197 important role to promote crystallization. The pulse time of $5 \mathrm{~s}$ was short and probably not 198 enough cavitation was generated to promote nucleation resulting in a slower crystallization. 199 On the other hand, a longer pulse duration such as 15 s produced a significant $(\mathrm{p}<0.001)$ 200 delay on induction time $(58.0 \pm 1.0 \mathrm{~min})$ that may be associated with increases of 201 temperature $\left(\Delta T=5.6^{\circ} \mathrm{C}\right)$ (Table 4) during the sonication. This increase in temperature is 202 associated to the dissipation of acoustic energy converted into heat [33]. Table 4 shows the 203 temperature increase for all sonicated samples. This table shows that the greatest temperature 204 increase was observed for the IESBO sonicated at $20 \mathrm{kHz}$ for $15 \mathrm{~s}$ using a $108 \mu \mathrm{m}$ pulse. 205 Even though sonication for longer times increased the induction time due to an increase in 206 temperature the SFC after 90 min was similar to the other sonicated samples $(p>0.05$, Table 207 2). These facts suggest that the thermal effect generated by HIU in longer pulse durations can 208 promote undesirable effects in the crystallization kinetics. 
Figure 1B shows SFC values as a function of time for the sample crystallized with and without HIU at $40 \mathrm{kHz}$ frequency. As observed for $20 \mathrm{kHz}$, sonicated IESBO using $40 \mathrm{kHz}$ waves presented higher values $(\mathrm{p}<0.0001)$ of solid fat content (Table 2$)$ than those observed in the sample crystallized without HIU $(0.2 \pm 0.0 \%)$ indicating that a sonication frequency of $40 \mathrm{kHz}$ also induced crystallization. However, SFC values obtained with $40 \mathrm{kHz}$ frequency were slightly lower than those observed at $20 \mathrm{kHz}$ frequency after $90 \mathrm{~min}$ (Table 2) but these differences were only significant $(\mathrm{p}<0.0001)$ for sample crystallized at $24 \mu \mathrm{m}$ for $10 \mathrm{~s}$ and at $108 \mu \mathrm{m}$ for $5 \mathrm{~s}$. This suggests that sonication using $40 \mathrm{kHz}$ frequency is also able to induce crystallization; however, higher power levels are needed to obtain a similar SFC after 90 min. When using $40 \mathrm{kHz}$ frequency and amplitude of $108 \mu \mathrm{m}$ for $15 \mathrm{~s}$, the plateau was reached after 77 min of crystallization, whereas when the same amplitude was applied for $10 \mathrm{~s} \mathrm{SFC}$ values reached a plateau after 87 min. Only samples sonicated using $108 \mu \mathrm{m}$ amplitude for 10 and $15 \mathrm{~s}$ were well fitted to the Gompertz equation with $\mathrm{R}^{2}$ values above 0.90 (Table 3 ).

222 This lack of fit for the milder sonication conditions $(24 \mu \mathrm{m}$ for $10 \mathrm{~s}$ and $108 \mu \mathrm{m}$ for $5 \mathrm{~s})$ is explained by the slow growth in SFC where the shape of the SFC curve did not follow a sigmoidal shape (Figure 1B). The kinetics parameters show that IESBO sonicated using amplitude of $108 \mu \mathrm{m}$ for 10 and $15 \mathrm{~s}$ had induction times of $51.9 \pm 1.2$ and $51.8 \pm 0.7 \mathrm{~min}$, respectively which were in the same order of magnitude than the ones obtained for the IESBO sonicated at $20 \mathrm{kHz}$. Sonication conditions at $20 \mathrm{kHz}$ that had the greater effect on SFC curves were the ones performed at $24 \mu \mathrm{m}$ and $108 \mu \mathrm{m}$ of amplitude for $10 \mathrm{~s}$. However, these conditions did not perform well for the $40 \mathrm{kHz}$ sonication conditions where the best conditions were obtained for samples sonicated at $108 \mu \mathrm{m}$ for longer time (10 and $15 \mathrm{~s}$ ). This again supports the hypothesis that a higher power level is needed when HIU is applied at a

232 higher frequency such as $40 \mathrm{kHz}$ compared to the $20 \mathrm{kHz}$ one. In addition, it is important to 233 note that temperature increases observed for the samples sonicated using the $40 \mathrm{kHz}$ wave 
234 are lower than the ones obtained for the $20 \mathrm{kHz}$ one (Table 4) and explains the efficiency of 235 the $40 \mathrm{kHz}$ sonication at $108 \mu \mathrm{m}$ for $15 \mathrm{~s}$.

Figure 1C shows SFC values as a function of time for IESBO crystallized using high-

237

238

239

240

241

242

243

244

245

246

247

248

249

250

251

252

253

254

255

256

257 speed agitation with two different probes and two speeds $(6,000$ and $24,000 \mathrm{rpm})$ for $10 \mathrm{~s}$. High-speed agitation was effective in promoting crystallization as shown by a significant increase $(\mathrm{p}<0.0001)$ in SFC for agitation values of 24,000 rpm (Table 2). As expected, higher agitation rate produces changes in crystallization [34]. With the exception of the sample crystallized using the big probe at $6,000 \mathrm{rpm}$ all other high-speed treated samples were well fitted to the Gompertz model (Table 3). Kinetic parameters (Table 3) showed shorter induction time $(\lambda)(\mathrm{p}<0.001)$ and slightly higher growth rate $(\mu)$ for samples agitated using the bigger probe and greater speed $(24,000 \mathrm{rpm})$. The SFC after $90 \mathrm{~min}$ of crystallization under this condition was significantly higher $(\mathrm{p}<0.0001)$ than the one obtained for the non-sonicated sample. Samples agitated at $24,000 \mathrm{rpm}$ reached a significantly higher SFC value $(\mathrm{p}<0.0001$, Table 2$)$ of $5.5 \pm 0.1 \%$ compared to the ones obtained for sonicated samples.

In order to understand differences in SFC observed between sonicated and agitated samples images and videos were captured during sonication and high-speed agitation (Figure 2, supplementary material). Figure $2 \mathrm{~A}$ and $2 \mathrm{~B}$ show bubbles generated during sonication using the higher tip amplitude $(108 \mu \mathrm{m})$ at 40 and $20 \mathrm{kHz}$, respectively; while Figure $2 \mathrm{C}$ and 2D show bubbles generated during the use of high-speed agitation using 24,000 rpm and $6,000 \mathrm{rpm}$ of speed respectively. These images show that a greater amount of bubbles and agitation is generated with the $20 \mathrm{kHz}$ tip compared to the $40 \mathrm{kHz}$ one for the same tip amplitude suggesting that cavitation events generated at $20 \mathrm{kHz}$ and $40 \mathrm{kHz}$ are different. Sonication at $20 \mathrm{kHz}$ produced mostly very small bubbles associated with shear and 
258 microstreaming events. Sonication at $40 \mathrm{kHz}$ produced larger bubbles that did not dissipate 259 so easily in the media with low shear and microstreaming. This corroborates our previous 260 hypothesis concerning the generation of fewer cavities during sonication at higher 261 frequencies. This hypothesis is also supported by the lower increase in temperature observed 262 for samples sonicated at $40 \mathrm{kHz}$ compared to the $20 \mathrm{kHz}$ samples (Table 4).

263 Figures $2 \mathrm{C}$ and 2D show IESBO treated with high-speed agitation $(24,000 \mathrm{rpm}$ or $2646,000 \mathrm{rpm}$ ) and through these images it is possible to observe that agitation levels produced 265 by the ultraturrax at the speed of $24,000 \mathrm{rpm}$ was much higher than the agitation produced by 266 sonication (20 and $40 \mathrm{kHz}$ ). This higher agitation levels explain the higher SFC obtained 267 using 24,000 rpm compared to the sonicated IESBO. However, the agitation produced at the 268 speed of $6,000 \mathrm{rpm}$ resembles that observed in the sonication using the frequency of $20 \mathrm{kHz}$. 269 The effect of high agitation on lipid crystallization has been widely described by others [22, 270 35-38]. Shear greatly accelerates nucleation resulting in higher crystallization rates and an 271 increased number of smaller crystals, which typically results in increased fat crystal network 272 strength [38]. It is known that shear provides enough energy to overcome activation energy 273 barriers and consequently increase the rate of primary nucleation [37]. IESBO crystallized 274 under high-speed agitation confirmed these statements (Figure 2C and 2D).

\section{Crystal Microstructure}

276 Polarized light microscopy (PLM) images of crystallized IESBO with and without HIU 277 at $44{ }^{\circ} \mathrm{C}$ are presented in Figure 3. The crystallization of IESBO without HIU started before 27850 min with the crystallization of few and weak birefringent clusters. After 90 min in the 279 crystallization cell these few irregular clusters increased in size and birefringence, but they 280 did not form a crystalline network, which eventually reflected the low SFC $(0.2 \pm 0.0 \%)$ 
281 observed in Table 2 and Figure 1. The images shown in Figure 3 support the results discussed

282 in the SFC section where all ultrasound treatments induced crystallization. Consequently, an 283 increase in the crystallized area is observed in the PLM images.

As previously described for the SFC data crystal microstructure show that the

285

286

287

288

289

290

291

292

293

294

295

296

297

298

299

300

301

302

303

304 frequency of $20 \mathrm{kHz}$ induced crystallization, mainly using amplitudes of 24 and $108 \mu \mathrm{m}$ for $10 \mathrm{~s}$ leading to a crystalline network formed by small lipid crystals and confirming the results showed by the kinetics parameters. Even though slight differences were observed in the crystallization kinetics (Table 3, Figure 1) as a function of tip amplitude and duration, the PLM images obtained after 90 min did not show significant differences in terms of crystal sizes and shapes. For IESBO sonicated at $40 \mathrm{kHz}$ a slight induction in crystallization was also observed at $50 \mathrm{~min}$; however, the crystalline network formed after 90 min was more open with bigger crystals compared to the ones observed using $20 \mathrm{kHz}$ frequency. Likewise, images of IESBO using $40 \mathrm{kHz}$ are coherent to previous results with big clusters of variable sizes were observed after 90 min of crystallization. The differences described above for SFC between 20 and $40 \mathrm{kHz}$ can also been seen in the PLM images. Samples sonicated using 20 $\mathrm{kHz}$ of frequency induced crystallization even at the lowest amplitude and slightly bigger clusters were observed in samples sonicated for $15 \mathrm{~s}$. Whereas for $40 \mathrm{kHz}$ of frequency the sonication only generated enough cavitation to form a crystalline lattice when the largest amplitudes were used at higher pulse times (108 $\mu \mathrm{m}$ for 10 and $15 \mathrm{~s})$

High-speed agitation induced fast crystallization mainly using 24,000 rpm independently of the probe used (Figure 4). After $50 \mathrm{~min}$ of crystallization, several small crystals were observed confirming the short induction time $(48.8 \pm 1.4$ min and $44.8 \pm 1.1$ min) reported in Table 3 compared to sonicated IESBO. After 90 min of crystallization, highspeed agitation at 24,000 rpm showed a homogeneous area of small spherulites and a 
305 crystalline network comparable with the ones obtained with sonication at $20 \mathrm{kHz}$. The effect 306 of agitation on crystal size was described by others [34, 39] showing perhaps evidence of a 307 secondary nucleation caused by crystal contact mechanism [37].

High-speed agitation at $6,000 \mathrm{rpm}$ also induced crystallization but after $50 \mathrm{~min}$ of crystallization only few big crystals were observed that after 90 min formed a dense network with heterogeneous clusters and voids between these clusters. Probably this speed $(6,000$ rpm) was not high enough to induce as much nucleation as the one generated using 24,000 rpm but was enough to enhance the rate of heat and mass transfer and to promote crystal growth [40].

\section{Melting Behavior}

Figure 5 shows the melting profile of IESBO measured by DSC when di $\square$ erent acoustic amplitudes and pulse duration were used at $20 \mathrm{kHz}$ (Figure 5A) and $40 \mathrm{kHz}$ (Figure

317 5B) frequencies and high-speed agitation (Figure $5 \mathrm{C}$ ). Table 5 shows onset $\left(T_{\text {on }},{ }^{\circ} \mathrm{C}\right)$, peak 318 temperatures $\left(T_{\mathrm{p}},{ }^{\circ} \mathrm{C}\right)$, and melting enthalpy $(\Delta \mathrm{H}, \mathrm{J} / \mathrm{g})$ obtained from these melting 319 thermograms (Figure 5).

DSC thermograms of the non-sonicated IESBO and of the IESBO sonicated with 20 $\mathrm{kHz}$ frequency (Figure 5A) show that sonication produces changes in the melting profiles.

322 The melting profile of the non-sonicated IESBO showed a main peak at $51.7 \pm 1.2{ }^{\circ} \mathrm{C}$ with a 323 shoulder at $59.39 \pm 1.25{ }^{\circ} \mathrm{C}$ indicating some level of fractionation. IESBO sonicated at a 324 frequency of $20 \mathrm{kHz}$ using $24 \mu \mathrm{m}$ of amplitude for $10 \mathrm{~s}$ and $108 \mu \mathrm{m}$ of amplitude for 5 and 32510 s showed melting profiles with only one peak, and this peak was sharper than the one 326 obtained for the non-sonicated sample and no shoulder was observed at higher temperatures. 327 This sharper melting peak suggest co-crystallization of the triacylglycerols (TAGs) promoted 
328 by sonication. Although no significant differences $(\mathrm{p}>0.05)$ were observed in $T_{\mathrm{p}}$ of 329 sonicated and non-sonicated samples (Table 5) values obtained for sonicated samples were 330 slightly lower that the ones obtained for the non-sonicated ones. The enthalpy of samples 331 sonicates using $24 \mu \mathrm{m}$ amplitude for $10 \mathrm{~s}$ and $108 \mu \mathrm{m}$ amplitude for 5 and $10 \mathrm{~s}$ were 332 significantly higher $(\mathrm{p}<0.05)$ than the ones obtained for the non-sonicated samples $($ Table 5) 333 indicating that the amount of crystallized fat was significantly higher for these samples, 334 which correspond to the higher SFC obtained after 90 min of crystallization (Table 2). 335 However, for samples sonicated using $108 \mu \mathrm{m}$ amplitude for $15 \mathrm{~s}$ the melting profile showed 336 a wider peak similar to the one observed for the non-sonicated IESBO. In addition, even 337 though enthalpy values for this sonicated sample was higher than the one obtained for the 338 non-sonicated sample, this difference was not significant $(\mathrm{p}>0.05)$.

339 Sonication at $40 \mathrm{kHz}$ did not affect melting profiles in a significant manner as melting 340 peaks of all sonicated samples were broad as the ones observed for the non-sonicated 341 samples (Figure 5B). Moreover, no differences $(p>0.05)$ were observed in $T_{p}$ or in melting 342 enthalpy values among the sonicated and non-sonicated samples. This lack of effect on the 343 melting behavior is probably due to the low degree of cavitation obtained at this frequency 344 as previously discussed.

345 The thermograms obtained for samples treated with high-speed agitation show that the 346 effects in melting behavior were totally different from sonicated samples. High-speed 347 agitation mainly at higher speeds $(24,000 \mathrm{rpm})$ shows signficant fractionation as evidenced 348 by a marked shoulder obtained at high temperatures $\left(55.74 \pm 0.39^{\circ} \mathrm{C}\right)$. This unexpected 349 result could be a consequence of air incoporation during high-speed agitation. The air 350 incorporated during the agitation is cooler than the crystallization temperature and therefore 351 induces the crystallization of high melting point TAGs. The amount of crystals was increased 
352 as shown by the enthalpy values and this increase was only significant $(\mathrm{p}<0.05)$ for samples 353 crystallized using the big probe at high speed $(24,000 \mathrm{rpm})$. The enthalpy values for agitation 354 using the 24,000 rpm were related to the results observed in SFC and PLM where higher 355 final SFC and higher crystallized area were obtained compared to the other speed.

\section{Viscoelastic Properties}

Figure 6 shows the storage or elastic modulus (G') of IESBO crystallized without and with sonication at 20 and $40 \mathrm{kHz}$ (Figure 6A) and high-speed agitation (Figure 6B) crystallized for $90 \mathrm{~min}$. IESBO sonicated at $20 \mathrm{kHz}$ using amplitudes of 24 and $108 \mu \mathrm{m}$ for $10 \mathrm{~s}$ and $108 \mu \mathrm{m}$ for $5 \mathrm{~s}$ showed a significantly higher $\mathrm{G}^{\prime}(\mathrm{p}<0.0001)$ than the ones obtained for non-sonicated IESBO and for IESBO sonicated using $108 \mu \mathrm{m}$ amplitude for $15 \mathrm{~s}$ (Figure 6A). The elasticity of sonicated IESBO at amplitudes of 24 and $108 \mu \mathrm{m}$ for $10 \mathrm{~s}$ and $108 \mu \mathrm{m}$ for $5 \mathrm{~s}$ at $20 \mathrm{kHz}$ frequency showed the highest increments $(80,218 \pm 15,384 \mathrm{~Pa}, 72,735 \pm$ 9,547 $\mathrm{Pa}$ and $67,727 \pm 16,797 \mathrm{~Pa}$, respectively) in $\mathrm{G}^{\prime}$ compared to the non-sonicated samples (436 $\pm 173 \mathrm{~Pa}$ ). The amplitude of $108 \mu \mathrm{m}$ for $15 \mathrm{~s}$ was not significantly different from the non-sonicated IESBO $(\mathrm{p}>0.05)$ probably due to the increment of $5.6{ }^{\circ} \mathrm{C}$ in temperature (Table 3) that occurred with higher pulse durations. Although there has been an increase in the elasticity of IESBO sonicated at $40 \mathrm{kHz}$ these increments were not significantly different 369 from the non-sonicated samples $(\mathrm{p}>0.05)$ (Figure 6A).

The elasticity of the IESBO subjected to high-speed agitation (Figure 6B) was significantly higher $(\mathrm{p}<0.0001)$ than non-sonicated ones only for samples crystallized using $37224,000 \mathrm{rpm}$ agitation with both probes. Despite the samples subjected to high-speed agitation 373 showed significantly higher SFC (Table 2) and the PLM (Figure 4) showed a microstructure 374 with a large crystallized area, which resembles the $20 \mathrm{kHz}$ frequency, the $\mathrm{G}$ 'values for 
375 $376 \pm 11.177$ and $39,950 \pm 23,828 \mathrm{~Pa}$ ) than the ones observed for IESBO sonicated at $20 \mathrm{kHz}$

$377(80,218 \pm 15,384 \mathrm{~Pa}$ for $24 \mu \mathrm{m}$ for $10 \mathrm{~s})$.

378

379

380

381

382

383

384

385

386

387

388

389

390

391

392

393

394

395

396

397

samples crystallized under 24,000 rpm agitation were significantly $(\mathrm{p}<0.05)$ smaller $(42,602$

These differences in elasticity of IESBO caused by the treatments $(20 \mathrm{kHz}, 40 \mathrm{kHz}$ and high-speed agitation) used in this study could be attributed to differences in microstructure observed in Figures 3 and 4. Smaller crystals observed in IESBO sonicated with $20 \mathrm{kHz}$ (24 $\mu \mathrm{m}$ for $10 \mathrm{~s}, 108 \mu \mathrm{m}$ for 5 and $10 \mathrm{~s})$ and high-speed agitation $(24,000 \mathrm{rpm})$ are associated with higher G' values. On the other hand, the highest SFC observed in IESBO crystallized with high-speed agitation $(5.5 \pm 0.1 \%)$ was not high enough to result in a higher elastic modulus $\left(\mathrm{G}^{\prime}\right)$. This means that in this case crystal morphology had a greater contribution in G' value than SFC values. A similar behavior was observed by Rincón-Cardona et al. [25] when they studied the crystallization of sonicated sample of a stearic fraction of high stearic high oleic sunflower oil where a higher SFC was not correlated to higher values of G'. These authors associated this behavior to different crystal morphologies and/or polymorphic forms obtained in the systems. The elasticity depends not only of macrostructural properties of the crystalline network but it is also related to interactions that occur at the molecular level [41].

\section{Conclusion}

This research demonstrated that the HIU can induce changes in physical properties of IESBO using 20 and $40 \mathrm{kHz}$ of frequency. These changes included solid fat content, microstructure, rheological and melting properties, however, these changes were more significant when using $20 \mathrm{kHz}$ of frequency in specific conditions of amplitude (24 and $108 \mu \mathrm{m})$ and pulse time (5 and $10 \mathrm{~s}$ ). An increase in a pulse time to $15 \mathrm{~s}$ for waves operating at $20 \mathrm{kHz}$ showed negative effects on physical properties due to a significant increase in temperature. Even 
though crystallization was also induced when higher frequencies of $40 \mathrm{kHz}$ were used higher 399 amplitude $(108 \mu \mathrm{m})$ for long pulse duration $(15 \mathrm{~s})$ were needed to effectively change the 400 physical properties since higher frequencies generated fewer cavities during sonication. 401 High-speed agitation showed that agitation also improved the physical properties of IESBO. 402 However samples crystallized under high speed agitation had different the melting profiles, 403 microstructure, and the elasticity than the sonicated samples. These results suggest that the 404 induction on crystallization by sonication is not only caused by the agitation of the system 405 but also by cavitation events that are enhanced at lower frequencies. Results from this study 406 help understand the unlying mechanisms that drive lipid sonocrystallization and are 407 fundamental for the implementation of this technology in an industrial setting.

408 Acknowledgments: This project was supported and approved by the Utah Agricultural 409 Experiment Station as project number 8968. Authors would like to thank Tom Tiffany from 410 ADM for providing the samples. 


\section{References}

412 [1] Rastogi NK (2011) Opportunities and challenges in application of ultrasound in food 413 processing. Crit Rev Food Sci 51:705-722

414 [2] Bermúdez-Aguirre D, Barbosa-Cánovas G (2011) Power Ultrasound to process dairy 415 products. In: Feng H, Barbosa-Cánovas G, Weiss J (eds) Ultrasound technologies for food 416 and bioprocessing, Springer, New York, 445-466

417 [3] Dolatowski, ZJ, Stadnik, J, Stasiak, D (2007) Applications of ultrasound in food 418 technology. Acta Sci Pol Technol Aliment 6:89-99

419 [4] Martini S. (2013) Sonocrystallization of Fats (SpringerBriefs in Food, Health, and 420 Nutrition). New York: Springer

421 [5] Lida Y, Tuziuti T, Yasui K, Towata A, Kozuka T (2008) Control of viscosity in starch 422 and polysaccharide solutions with ultrasound after gelatinization. Innov Food Sci Emerg 423 Technol 9:140-146

424 [6] Leong TSH, Wooster, TJ, Kentish SE, Ashokkumar M (2009) Minimising oil droplet size 425 using ultrasonic emulsification. Ultrason Sonoch 16:721-727

426 [7] Caia M, Wanga S, Zheng Y, Lianga H (2009) Effects of ultrasound on ultrafiltration of 427 Radix astragalus extract and cleaning of fouled membrane, Separ Purific Technol 68:351428356.

429 [8] Champadrala J, Oliver C, Kentish, S, Ashokkumar M (2012). Ultrasonics Muthupandian $430 \quad$ Ultrason Sonoch 19:975-983 
431 [9] Shanmugama A, Ashokkumar, M, (2014) Functional properties of ultrasonically 432 generated flaxseed oil-dairy emulsions Ultrason Sonoch 21:1649-1657

433 [10] Abid M, Jabbar, S, Wu T, Hashim, MM, Hu B, Lei S, Zeng X (2014). Sonication 434 enhances polyphenolic compounds, sugars, carotenoids and mineral elements of apple juice. 435 Ultrason Sonoch 21:93-97

436 [11] Rossi D, Jamshidi R, Saffari N, Kuhn S, Gavriilidis A, Mazzei L (2015) Continuous437 Flow sonocrystallization in droplet-based microfluidics. Cryst Growth Des 15:5519-5529

438 [12] Fijlkowska A, Nowacka M, Winktor A, Sleddz M, Witrowa-Rajchertfd FD (2016) 439 Ultrasound as a pretreatment method to improve drying kinetics and sensory proprieties of 440 dried apple. J Food Proc Eng 39:256-265

441 [13] Eldalatony MM, Kabra AN, Hwang JH, Govindwar SP, Kim KJ, Kim, H, Jeon BH 442 (2016) Pretreatment of microalgal biomass for enhanced recovery/extraction of reducing 443 sugars and proteins Bioprocess Biosyst Eng 39:95-103

444 [14] Jamshidi R, Rossi D, Saffari N, Gavriilidis A, Mazzei L (2016) Investigation of the 445 effect of ultrasound parameters on continuous sonocrystallization in a millifluidic device. 446 Cryst Growth Des 16: 4607-4619

447 [15] Maruyama JM, Wagh A, Gioielli LA, Silva RC, Martini S (2016) Effects of high 448 intensity ultrasound and emulsifiers on crystallization behavior of coconut oil and palm olein. $449 \quad$ Food Res 86:54-63 
450 [16] Higaki K, Ueno S, Koyano T, Sato K. (2001). Effects of ultrasonic irradiation on 451 crystallization behavior of tripalmitoylglycerol and cocoa butter. J Am Oil Chem Soc $452 \quad 78: 513-518$

453 [17] Higaki K, Sasakura Y, Koyno T, Hachiya I, Sato K (2003) Physical analyses of gel $\square$ like 454 behavior of binary mixtures of high $\square$ melting and low $\square$ melting fats. J Am Oil Chem 80:263$455 \quad 270$

456 [18] Martini S, Herrera ML. 2008. Physical properties of low-trans shortenings as affected by 457 emulsifiers and storage conditions. Eur J Lipid Sci Technol 110:172-182

458 [19] Martini S, Tejeda-Pichardo R, Ye Y, Padilla SG, Shen FK, Doyle T. (2012). Bubble and 459 crystal formation in lipid systems during high-intensity insonation. J Am Oil Chem Soc $460 \quad 89: 1921-1928$

461 [20] Chen F, Zhang H, Sun X, Wang X, Xu X. (2013). Effects of ultrasonic parameters on 462 the crystallization behavior of palm oil. J Am Oil Chem Soc 90:941-949

463 [21] Frydenberg RP, Hammershoj M, Andersen U, Wiking L. (2013). Ultrasonication affects 464 crystallization mechanisms and kinetics of anhydrous milk fat. Cryst Growth Des 13:5375$465 \quad 5382$

466 [22] Sato K, Bayés-García L, Calvet T, Cuevas-Diarte MÀ, Ueno S (2013) External factors 467 affecting polymorphic crystallization of lipids. Eur J Lipid Sci Technol, 115:1224-1238

468 [23] Suzuki A, Lee J, Padilla S, Martini S (2010) Altering functional properties of fats using 469 power ultrasound. J Food Sci 75:E208-E214 
470 [24] Ye Y, Martini S. (2015). Application of high intensity ultrasound to palm oil in a 471 continuous system. J. Agric.Food Chem. 63:319-27

472 [25] Rincon-Cardona JA, Agudelo-Laverde LM, Martini S, Candal RJ, Herrera ML. (2015).

473 In situ synchrotron radiation X-ray scattering study on the effect of a stearic sucrose ester on 474 polymorphic behavior of a new sunflower oil variety. Food Res Int 64:9-17

475 [26] Wohlgemuth K, Kordylla A, Ruether F, Schembecker G (2009) Experimental study of 476 the effect of bubbles on nucleation during batch cooling crystallization. Chem Eng Sci $477 \quad 64: 4155-4163$

478 [27] Nalajala VS, Moholkar VS. (2011) Investigations in the physical mechanism of 479 sonocrystallization. Ultrason Sonochem 18:345-355.

480 [28] Ratsimba B, Biscans B, Delmas H, Jenck J. (1999) Sonocrystallization: the end of 481 empiricism? A review on the fundamental investigations and the industrial developments. 482 KONA 17:38-48

483 [29] Kloek W, Walstra P, van Vliet T (2000) Crystallization kinetics of fully hydrogenated 484 palm oil in sunflower oil mixtures. J Am Oil Chem Soc 77:389-398

485 [30] Foubert I, Dewettinck K, Vanrolleghem PA (2003) Modelling of the crystallization 486 kinetics of fats. Trends Food Sci Technol 14:79-92

487 [31] Farmani J (2015) Modeling of solid fat content of chemically interesterified fully 488 hydrogenated soybean oil and canola oil blends as a function of temperature and saturated 489 fatty acids. Food Meas 9:281-289 
490 [32] Toro-Vazquez, Herrera-Coronado, Dibildox-Alvarado, Charo-Alonso, \& Gomez-Aldapa 491 (2002) The avrami index and the fractal dimension in vegetable oil crystallization J Am Oil 492 Chem Soc 79:855-866.

493 [33] Kentish S, Ashokkumar M (2011) The Physical and Chemical Effects of Ultrasound In: 494 Feng H, Barbosa-Cánovas G, Weiss J (eds) Ultrasound technologies for food and 495 bioprocessing, Springer, New York, 1-12

496 [34] Herrera ML, Hartel RW (2000) Effect of processing conditions on crystallization 497 kinetics of a milk fat model system. J Am Oil Chem Soc 77:1177-1188

498 [35] Bayés-García L, Patel AR, Dewettinck K, Rousseau D, Sato K, Ueno S (2015) Lipid 499 crystallization kinetics - roles of external factors influencing functionality of end products 500 Cur Opin Food Sci 4:32-38

501 [36] De Graef V., Van Puyvelde P., Goderis B. and Dewettinck K. (2009). Influence of shear 502 flow on polymorphic behavior and microstructural development during palm oil 503 crystallization. Eur. J. Lipid Sci. Technol., 111, 290-302.

504 [37] Hartel RW (2001) Nucleation crystallization in foods. Aspen Publishers Inc, 505 Gaithersburg, 145-191

506 [38] Tran T, Rousseau, D. (2016) Influence of shear on fat crystallization. Food Res Intern $507 \quad 81: 157163$

508 [39] Martini S, Herrera ML, Hartel RW (2002) Effect of processing conditions on 509 microstructure of milk fat fraction/sunflower oil blends. J Am Oil Chem Soc 79:1063-1068 
1

2

3

4

5

6

7

8

9

10

11

12

13

14

15

16

17

18

19

20

21

22

23

24

25

26

27

28

29

30

31

32

33

34

35

36

37

38

39

40

41

42

43

44

45

46

47

48

49

50

51

52

53

54

55

56

57

58

59

60

510 [40] Campos R, Marangoni AG: (2014) Crystallization dynamics of shear worked cocoa

511 butter. Cryst Growth Des, 14:1199-1210

512 [41] Narine S, Marangoni A (2001) Elastic modulus as an indicator of macroscopic hardness

513 of fat crystal networks Lebensm-Wiss Technol. 34:33-40 


\section{$514 \quad$ Figure legends}

515 Figure 1. SFC of IESBO during $90 \mathrm{~min}$ of crystallization at $44{ }^{\circ} \mathrm{C}$ (control, open circles). 516 Samples were crystallized with HIU (solid symbols) operating at $20 \mathrm{kHz}$ (A), $40 \mathrm{kHz}$ (B) and 517 with high speed agitation (C).

518 Figure 2. Images of IESBO crystallized at $44^{\circ} \mathrm{C}$ using $\mathrm{HIU}$ at 20 and $40 \mathrm{kHz}$ and high-speed 519 agitation.

520 Figure 3. Polarized-light microscopy (PLM) images of IESBO crystallized at $44{ }^{\circ} \mathrm{C}$ without 521 and with high-intensity ultrasound pulse using 20 and $40 \mathrm{kHz}$ frequency. White bar in the 522 first picture represents $100 \mu \mathrm{m}$.

523 Figure 4. Polarized-light microscopy (PLM) images of IESBO crystallized at $44{ }^{\circ} \mathrm{C}$ without 524 and with high-speed agitation at 6,000 and $24,000 \mathrm{rpm}$. White bar in the first picture 525 represents $100 \mu \mathrm{m}$.

526 Figure 5. DSC melting profiles of IESBO crystallized for $90 \mathrm{~min}$ without and with HIU 527 using $20 \mathrm{kHz}$ (Figure 5A) and $40 \mathrm{kHz}$ (Figure 5B) of frequency. Melting profiles of samples 528 crystallized using high-speed Agitation are shown in Figure 5C.

529 Figure 6. Elastic modulus (G') of IESBO crystallized for 90 min without and with HIU using 53020 and $40 \mathrm{kHz}$ frequency (Figure 6A) and high-speed agitation (Figure 6B). Data with 531 different letters are statistically different $(\alpha=0.05)$. 
533 Table 1. Triacylglycerol and diacylglycerol composition (\%) of IESBO.

\begin{tabular}{lc}
\hline & IESBO \\
\hline DAG & $0.8 \pm 0.0$ \\
LLnLn & $0.8 \pm 0.0$ \\
LLLn & $3.1 \pm 0.1$ \\
LnLnO & $0.2 \pm 0.0$ \\
LLL & $6.2 \pm 0.0$ \\
OLLn & $1.8 \pm 0.1$ \\
PLLn & $2.1 \pm 0.0$ \\
LLO+OOLn & $6.9 \pm 0.1$ \\
PLL+POLn & $10.2 \pm 0.1$ \\
SLLn & $0.3 \pm 0.1$ \\
OOL & $2.7 \pm 0.1$ \\
POL+SLL+SOLn & $16.7 \pm 0.1$ \\
PPL+PSLn & $2.6 \pm 0.1$ \\
MPP & $0.1 \pm 0.0$ \\
OOO & $0.4 \pm 0.0$ \\
POO+SOL & $9.8 \pm 0.1$ \\
POP+PLS+SLnS & $9.3 \pm 0.1$ \\
GOO & $0.2 \pm 0.0$ \\
SOO & $1.8 \pm 0.1$ \\
POS+SLS & $11.9 \pm 0.1$ \\
PPS & $0.9 \pm 0.0$ \\
AOO & $0.1 \pm 0.1$ \\
SOS & $4.0 \pm 0.1$ \\
PSS & $3.3 \pm 0.2$ \\
BOO & $0.1 \pm 0.0$ \\
SSG+SAO & $0.3 \pm 0.1$ \\
SSS & $2.9 \pm 0.5$ \\
\hline
\end{tabular}

DAG: Diacylglycerols, L: linoleic acid, Ln: linolenic acid, O: oleic acid, P: palmitic acid, S: stearic acid, M: myristic acid; A: arachidic acid, G: gondoic acid; B: behenic acid 
552 Table 2. Solid fat content of IESBO after sonication using 20 and $40 \mathrm{kHz}$ of frequency and 553 using high-speed agitation (Mean \pm SD). Data with different superscripts are statistically 554 different $(\alpha=0.05)$.

\begin{tabular}{|c|c|c|}
\hline & $20 \mathrm{kHz}$ & $40 \mathrm{kHz}$ \\
\hline Wo HIU & \multicolumn{2}{|c|}{$0.238 \pm 0.028^{f}$} \\
\hline $24 \mu \mathrm{m}$ for $10 \mathrm{~s}$ & $3.68 \pm 0.17^{\mathrm{bc}}$ & $2.14 \pm 0.03^{\mathrm{e}}$ \\
\hline $108 \mu \mathrm{m}$ for $5 \mathrm{~s}$ & $4.29 \pm 0.04^{\mathrm{b}}$ & $3.38 \pm 0.21^{\mathrm{cd}}$ \\
\hline $108 \mu \mathrm{m}$ for $10 \mathrm{~s}$ & $3.95 \pm 0.13^{b c}$ & $3.42 \pm 0.28^{\mathrm{cd}}$ \\
\hline \multirow[t]{2}{*}{$108 \mu \mathrm{m}$ for $15 \mathrm{~s}$} & $3.71 \pm 0.21^{\mathrm{bc}}$ & $3.69 \pm 0.02^{b c}$ \\
\hline & \multicolumn{2}{|c|}{ High-speed agitation } \\
\hline Small Probe (6,000 rpm) & \multicolumn{2}{|c|}{$3.44 \pm 0.39^{\mathrm{cd}}$} \\
\hline Small Probe (24,000 rpm) & \multicolumn{2}{|c|}{$5.47 \pm 0.06^{\mathrm{a}}$} \\
\hline Big Probe $(6,000$ rpm) & \multicolumn{2}{|c|}{$2.92 \pm 0.62^{\mathrm{d}}$} \\
\hline Big Probe $(24,000$ rpm) & \multicolumn{2}{|c|}{$5.42 \pm 0.22^{\mathrm{a}}$} \\
\hline
\end{tabular}


556 Table 3. Kinetic parameters obtained from the Gompertz model corresponding to isothermal 557 crystallization of IESBO without and with sonication at 20 and $40 \mathrm{kHz}$ and using high-speed 558 agitation (Mean \pm SD). Data with different superscripts are statistically different $(\alpha=0.05)$.

\section{$20 \mathrm{kHz}$}

\begin{tabular}{|c|c|c|c|c|c|}
\hline & Wo HIU* & $24 \mu \mathrm{m} / 10 \mathrm{~s}$ & $108 \mu \mathrm{m} / 5 \mathrm{~s}$ & $108 \mu \mathrm{m} / 10 \mathrm{~s}$ & $108 \mu \mathrm{m} / 15 \mathrm{~s}$ \\
\hline$S F C_{\max }(\%)$ & $0.2 \pm 0.0$ & $3.8 \pm 0.1^{\mathrm{c}, \mathrm{d}}$ & $4.8 \pm 0.4^{\mathrm{b}, \mathrm{c}}$ & $4.0 \pm 0.0^{\mathrm{c}, \mathrm{d}}$ & $4.6 \pm 0.5^{b, c, d}$ \\
\hline$\mu\left(\% \min ^{-1}\right)$ & $0.01 \pm 0.0$ & $0.20 \pm 0.0^{\mathrm{a}}$ & $0.16 \pm 0.0^{\mathrm{b}}$ & $0.20 \pm 0.0^{\mathrm{a}}$ & $0.12 \pm 0.01^{\mathrm{c}, \mathrm{d}}$ \\
\hline$\lambda(\min )$ & $46.5 \pm 3.9$ & $51.1 \pm 0.7^{\mathrm{bc}}$ & $52.7 \pm 1.4^{\mathrm{b}}$ & $50.8 \pm 0.5^{\mathrm{bc}}$ & $58.0 \pm 1.0^{\mathrm{a}}$ \\
\hline$r^{2}$ & 0.71 & 0.96 & 0.91 & 0.98 & 0.93 \\
\hline
\end{tabular}

\section{$40 \mathrm{kHz}$}

\begin{tabular}{lccccc}
\hline & Wo HIU* & $\mathbf{2 4} \boldsymbol{\mu m} / \mathbf{1 0} \mathbf{s}^{*}$ & $\mathbf{1 0 8} \boldsymbol{\mu m} / \mathbf{5} \mathbf{~ s}^{*}$ & $\mathbf{1 0 8} \boldsymbol{\mu m} / \mathbf{1 0 ~ s}$ & $\mathbf{1 0 8} \boldsymbol{\mu m} / \mathbf{1 5} \mathbf{~ s}$ \\
\hline $\boldsymbol{S F C}_{\boldsymbol{m a x}}(\%)$ & $0.2 \pm 0.0$ & $8.8 \pm 7.7$ & $7.5 \pm 3.3$ & $3.4 \pm 0.2^{\mathrm{d}}$ & $3.7 \pm 0.1^{\mathrm{c}, \mathrm{d}}$ \\
$\boldsymbol{\mu}\left(\boldsymbol{\%} \mathbf{m i n}^{-1}\right)$ & $0.01 \pm 0.0$ & $0.08 \pm 0.0$ & $0.11 \pm 0.0$ & $0.11 \pm 0.0^{\mathrm{d}}$ & $0.16 \pm 0.0^{\mathrm{b}}$ \\
$\lambda(\boldsymbol{m i n})$ & $46.2 \pm 3.9$ & $65.1 \pm 12.8$ & $59.9 \pm 3.7$ & $51.9 \pm 1.2^{\mathrm{bc}}$ & $51.8 \pm 0.7^{\mathrm{bc}}$ \\
$r^{2}$ & 0.71 & 0.85 & 0.86 & 0.92 & 0.96 \\
\hline
\end{tabular}

\section{High-Speed Agitation}

\begin{tabular}{|c|c|c|c|c|c|}
\hline & Wo HIU* & $\begin{array}{l}\text { Small probe } \\
(6,000 \mathrm{rpm})\end{array}$ & $\begin{array}{l}\text { Small probe } \\
(24,000 \text { rpm })\end{array}$ & $\begin{array}{c}\text { Big probe } \\
(6,000 \text { rpm })^{*}\end{array}$ & $\begin{array}{c}\text { Big probe } \\
(24,000 \text { rpm) }\end{array}$ \\
\hline$S F C_{\max }(\%)$ & $0.2 \pm 0.0$ & $3.8 \pm 0.4^{\mathrm{c}, \mathrm{d}}$ & $6.3 \pm 0.7^{\mathrm{a}}$ & $4.1 \pm 1.4$ & $5.7 \pm 0.2^{\mathrm{a}, \mathrm{b}}$ \\
\hline$\mu\left(\% \min ^{-1}\right)$ & $0.01 \pm 0.0$ & $0.10 \pm 0.01^{\mathrm{d}}$ & $0.15 \pm 0.01^{\mathrm{b}, \mathrm{c}}$ & $0.09 \pm 0.01$ & $0.17 \pm 0.01^{\mathrm{b}, \mathrm{a}}$ \\
\hline$\lambda(\min )$ & $46.5 \pm 3.9$ & $53.6 \pm 1.3^{\mathrm{b}}$ & $48.8 \pm 1.4^{\mathrm{c}}$ & $56.2 \pm 2.6$ & $44.8 \pm 1.1^{\mathrm{d}}$ \\
\hline$r^{2}$ & 0.71 & 0.90 & 0.90 & 0.67 & 0.93 \\
\hline
\end{tabular}

$559 \quad \mathrm{SFC}_{\max }(\%)=$ final solid fat content, $\mu\left(\% \mathrm{~min}^{-1}\right)=$ maximal growth rate, $\lambda(\mathrm{min})=$ induction time

$560 *$ ANOVA was performed only for samples that fitted to the Gompertz equation with $\mathrm{R}^{2}$ above 0.90 . 
561 Table 4. Increase in temperature $\left(\Delta \mathrm{T}=\mathrm{T}_{\mathrm{f}}-\mathrm{T}_{\mathrm{i}}\right)$ obtained after sonication using 20 and 40 $562 \mathrm{kHz}$ frequency $($ Mean $\pm \mathrm{SD}) . \mathrm{T}_{\mathrm{f}}=$ Final temperature, $\mathrm{T}_{\mathrm{i}}=$ Initial temperature, 563

\begin{tabular}{lcc}
\hline & $\mathbf{2 0} \mathbf{~ k H z}$ & $\mathbf{4 0 ~} \mathbf{~ H z}$ \\
\hline $\mathbf{2 4} \boldsymbol{\mu m}$ for $10 \mathrm{~s}$ & $1.6 \pm 0.4$ & $0.2 \pm 0.1$ \\
$\mathbf{1 0 8} \boldsymbol{\mu m}$ for $\mathbf{5} \mathrm{s}$ & $0.7 \pm 0.3$ & $0.5 \pm 0.1$ \\
$\mathbf{1 0 8} \boldsymbol{\mu m}$ for $\mathbf{1 0} \mathrm{s}$ & $1.0 \pm 0.2$ & $0.6 \pm 0.0$ \\
$\mathbf{1 0 8} \boldsymbol{\mu m}$ for $\mathbf{1 5} \mathrm{s}$ & $5.6 \pm 0.8$ & $2.1 \pm 0.2$ \\
\hline
\end{tabular}


564 Table 5. Melting parameters of IESBO crystallized at $44{ }^{\circ} \mathrm{C}$ for $90 \mathrm{~min}$ without and with 565 HIU and with high-speed agitation (Mean \pm SD). Samples were sonicated using $20 \mathrm{kHz}$ and $56640 \mathrm{kHz}$ frequency. $T_{\text {on }}$ : onset temperature, $T_{\mathrm{p}}$ : peak temperature, and $\Delta \mathrm{H}$ : melting enthalpy.

567 Data with different superscripts are statistically different $(\alpha=0.05)$

\begin{tabular}{|c|c|c|c|}
\hline & \multicolumn{3}{|c|}{$20 \mathrm{kHz}$} \\
\hline & $\mathrm{T}_{\text {on }}\left({ }^{\circ} \mathrm{C}\right)$ & $\mathrm{T}_{\mathrm{p}}\left({ }^{\circ} \mathrm{C}\right)$ & $\Delta \mathbf{H}(\mathbf{J} / \mathbf{g})$ \\
\hline Wo HIU & $47.7^{*}$ & $51.7 \pm 1.2^{\mathrm{a}}$ & $6.5 \pm 2.7^{\mathrm{d}}$ \\
\hline $24 \mu \mathrm{m}$ for $10 \mathrm{~s}$ & $46.9 \pm 1.4$ & $49.7 \pm 0.5^{\mathrm{a}}$ & $11.3 \pm 0.6^{\mathrm{a}, \mathrm{b}, \mathrm{c}}$ \\
\hline $108 \mu \mathrm{m}$ for $5 \mathrm{~s}$ & $46.4 \pm 0.1$ & $50.1 \pm 0.5^{\mathrm{a}}$ & $11.7 \pm 1.6^{\mathrm{a}, \mathrm{b}}$ \\
\hline $108 \mu \mathrm{m}$ for $10 \mathrm{~s}$ & $45.4 \pm 0.4$ & $49.8 \pm 0.1^{\mathrm{a}}$ & $10.5 \pm 1.1^{\mathrm{a}, \mathrm{b}, \mathrm{c}}$ \\
\hline $108 \mu \mathrm{m}$ for $15 \mathrm{~s}$ & $46.8 \pm 1.2$ & $49.8 \pm 0.9^{\mathrm{a}}$ & $8.5 \pm 0.6^{\mathrm{b}, \mathrm{c}, \mathrm{d}}$ \\
\hline
\end{tabular}

\section{$40 \mathrm{kHz}$}

\begin{tabular}{lccc}
\hline Wo HIU & $47.7^{*}$ & $51.7 \pm 1.2^{\mathrm{a}}$ & $6.5 \pm 2.7^{\mathrm{d}}$ \\
$\mathbf{2 4} \boldsymbol{\mu}$ for $\mathbf{1 0} \mathbf{s}$ & $48.1 \pm 0.0$ & $51.7 \pm 0.7^{\mathrm{a}}$ & $5.5 \pm 1.7^{\mathrm{d}}$ \\
$\mathbf{1 0 8} \boldsymbol{\mu} \mathbf{m}$ for $\mathbf{5} \mathbf{s}$ & $46.8 \pm 0.7$ & $51.2 \pm 1.6^{\mathrm{a}}$ & $6.5 \pm 2.2^{\mathrm{d}}$ \\
$\mathbf{1 0 8} \boldsymbol{\mu} \mathbf{m}$ for $\mathbf{1 0} \mathbf{s}$ & $46.7 \pm 1.0$ & $52.6 \pm 3.2^{\mathrm{a}}$ & $8.4 \pm 0.9^{\mathrm{b}, \mathrm{c}, \mathrm{d}}$ \\
$\mathbf{1 0 8} \boldsymbol{\mu} \mathbf{m}$ for $\mathbf{1 5} \mathbf{s}$ & $47.8 \pm 1.2$ & $51.4 \pm 2.7^{\mathrm{a}}$ & $7.3 \pm 1.9^{\mathrm{c}, \mathrm{d}}$ \\
\hline
\end{tabular}

\section{HIGH-SPEED AGITATION}

\begin{tabular}{lccc}
\hline Wo HIU & $47.7^{*}$ & $51.7 \pm 1.2^{\mathrm{a}}$ & $6.5 \pm 2.7^{\mathrm{d}}$ \\
Small Probe (24000 rpm) & $45.9 \pm 0.5$ & $49.2 \pm 0.5^{\mathrm{a}}$ & $10.6 \pm 1.4^{\mathrm{a}, \mathrm{b}, \mathrm{c}, \mathrm{d}}$ \\
Small Probe (6000 rpm) & $47.6 \pm 0.4$ & $51.0 \pm 0.8^{\mathrm{a}}$ & $6.3 \pm 1.1^{\mathrm{d}}$ \\
Big Probe (24000 rpm) & $46.2 \pm 0.4$ & $51.6 \pm 2.4^{\mathrm{a}}$ & $12.8 \pm 3.6^{\mathrm{a}}$ \\
Big Probe (6000 rpm) & $46.2 \pm 0.6$ & $49.3 \pm 0.6^{\mathrm{a}}$ & $9.5 \pm 1.6^{\mathrm{a}, \mathrm{b}, \mathrm{c}, \mathrm{d}}$ \\
\hline
\end{tabular}


$20 \mathrm{kHz}$
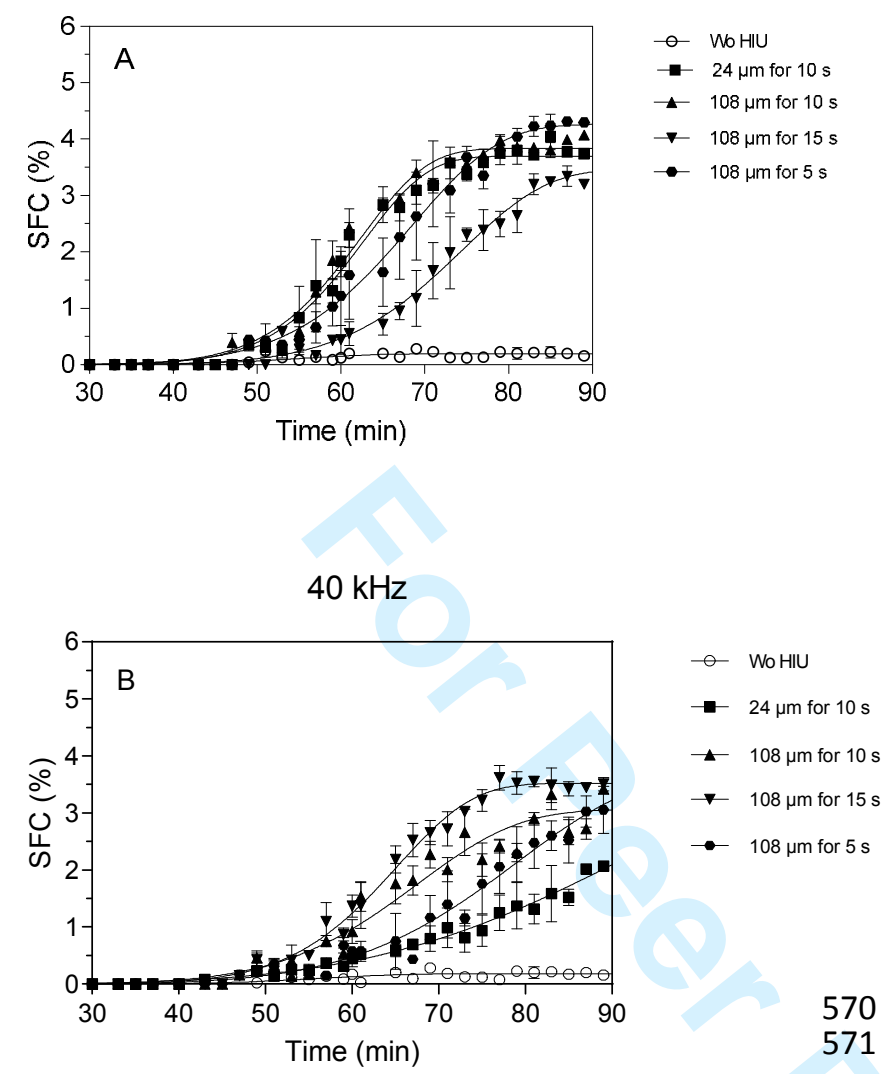

$$
\begin{aligned}
& -\quad \text { Wo HIU } \\
& -24 \mu \mathrm{m} \text { for } 10 \mathrm{~s} \\
& -108 \mu \mathrm{m} \text { for } 10 \mathrm{~s} \\
& \rightarrow 108 \mu \mathrm{m} \text { for } 15 \mathrm{~s} \\
& -108 \mu \mathrm{m} \text { for } 5 \mathrm{~s}
\end{aligned}
$$

571
569

High-Speed Agitation

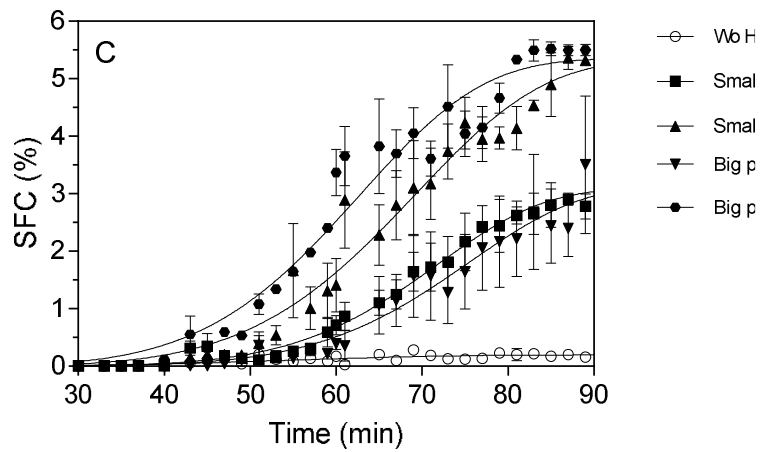

572 Figure 1. SFC of IESBO during $90 \mathrm{~min}$ of crystallization at $44{ }^{\circ} \mathrm{C}$ (control, open circles).

573 Samples were crystallized with HIU (solid symbols) operating at $20 \mathrm{kHz}(\mathrm{A}), 40 \mathrm{kHz}$ (B) and 574 with high speed agitation (C). 


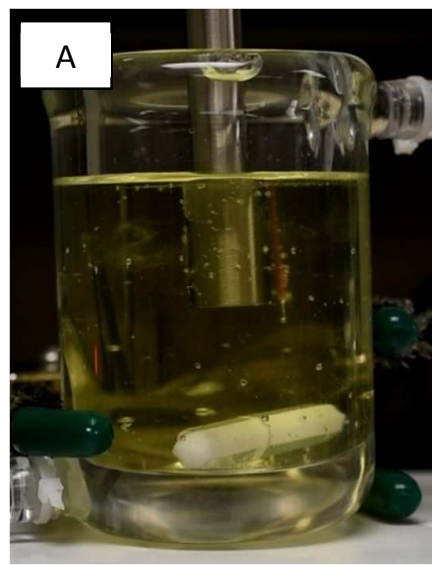

$108 \mu \mathrm{m}(40 \mathrm{kHz})$

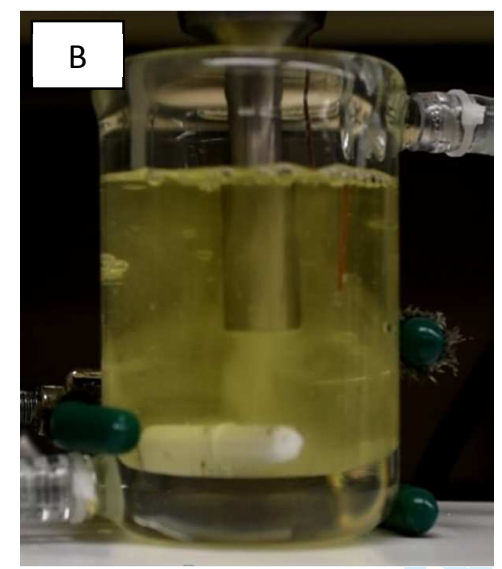

$108 \mu \mathrm{m}(20 \mathrm{kHz})$

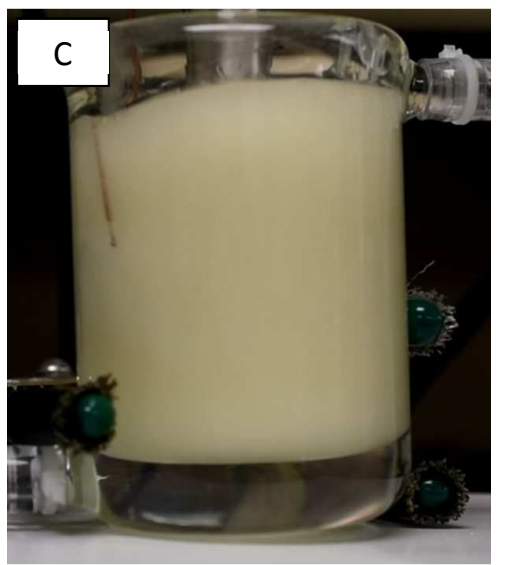

High-speed agitation

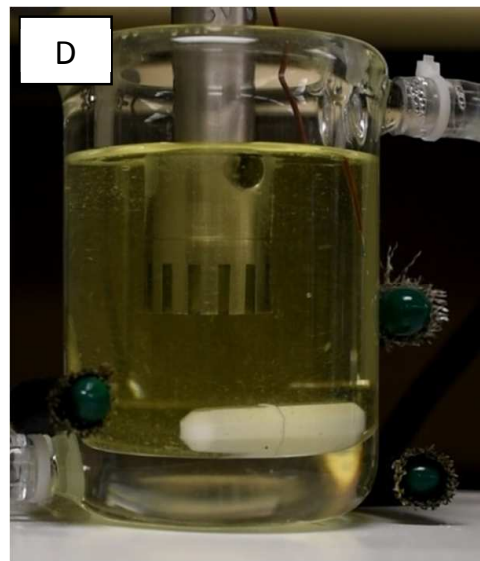

High-speed agitation $(6,000 \mathrm{rpm})$

575 Figure 2. Images of IESBO crystallized at $44{ }^{\circ} \mathrm{C}$. These images were captured during the treatments of sonication at $40 \mathrm{kHz}(\mathrm{A}), 20 \mathrm{kHz}(\mathrm{B})$ at 576 amplitude $108 \mu \mathrm{m}$ and high-speed agitation at 24,000 rpm (C) and 6,000 rpm (D) - videos are submitted as supplementary material. 


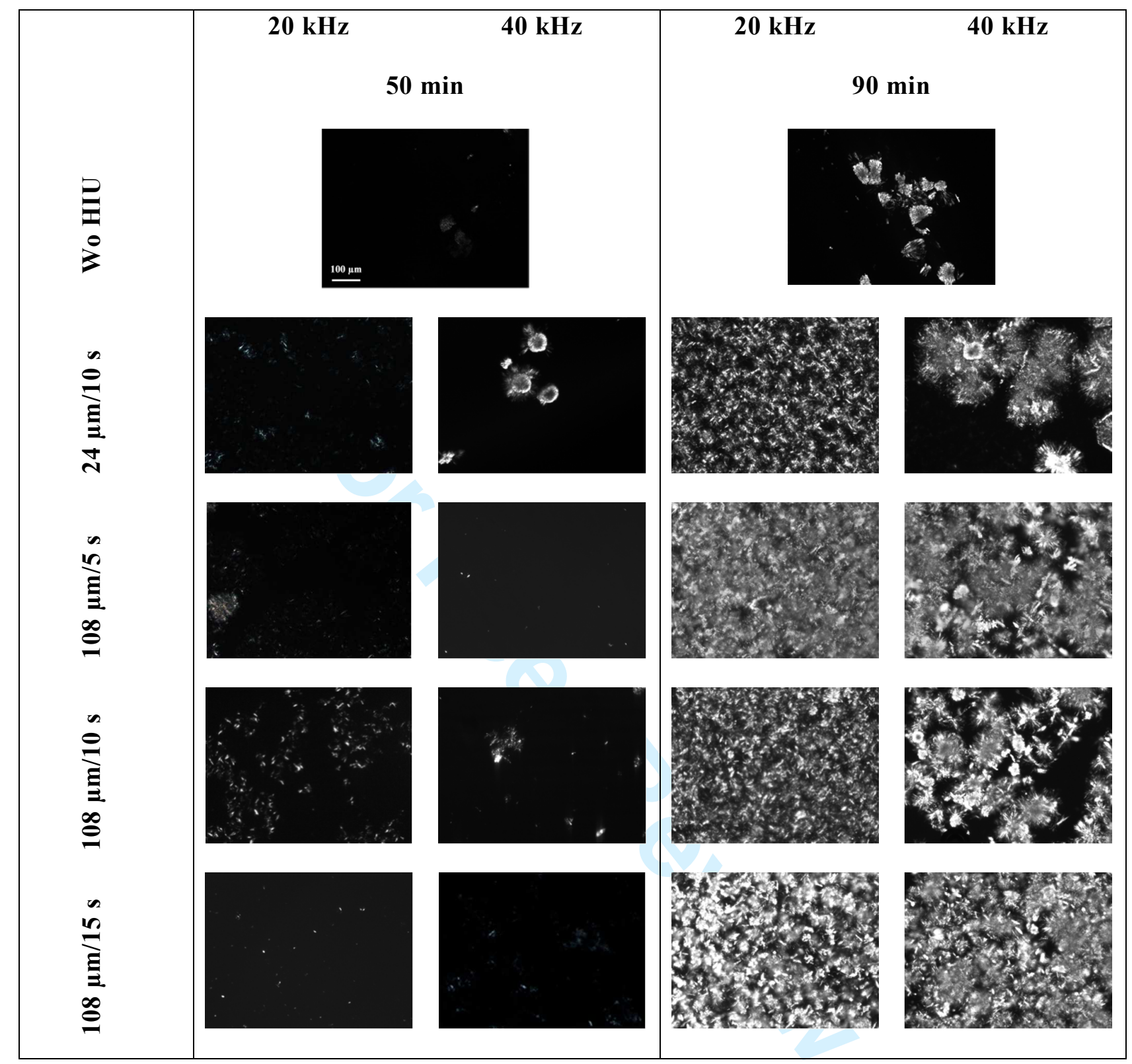

\section{7}

578 Figure 3. Polarized-light microscopy (PLM) images of IESBO crystallized at $44{ }^{\circ} \mathrm{C}$ without 579 and with high-intensity ultrasound pulse using 20 and $40 \mathrm{kHz}$ frequency. White bar in the 580 first picture represents $100 \mu \mathrm{m}$. 


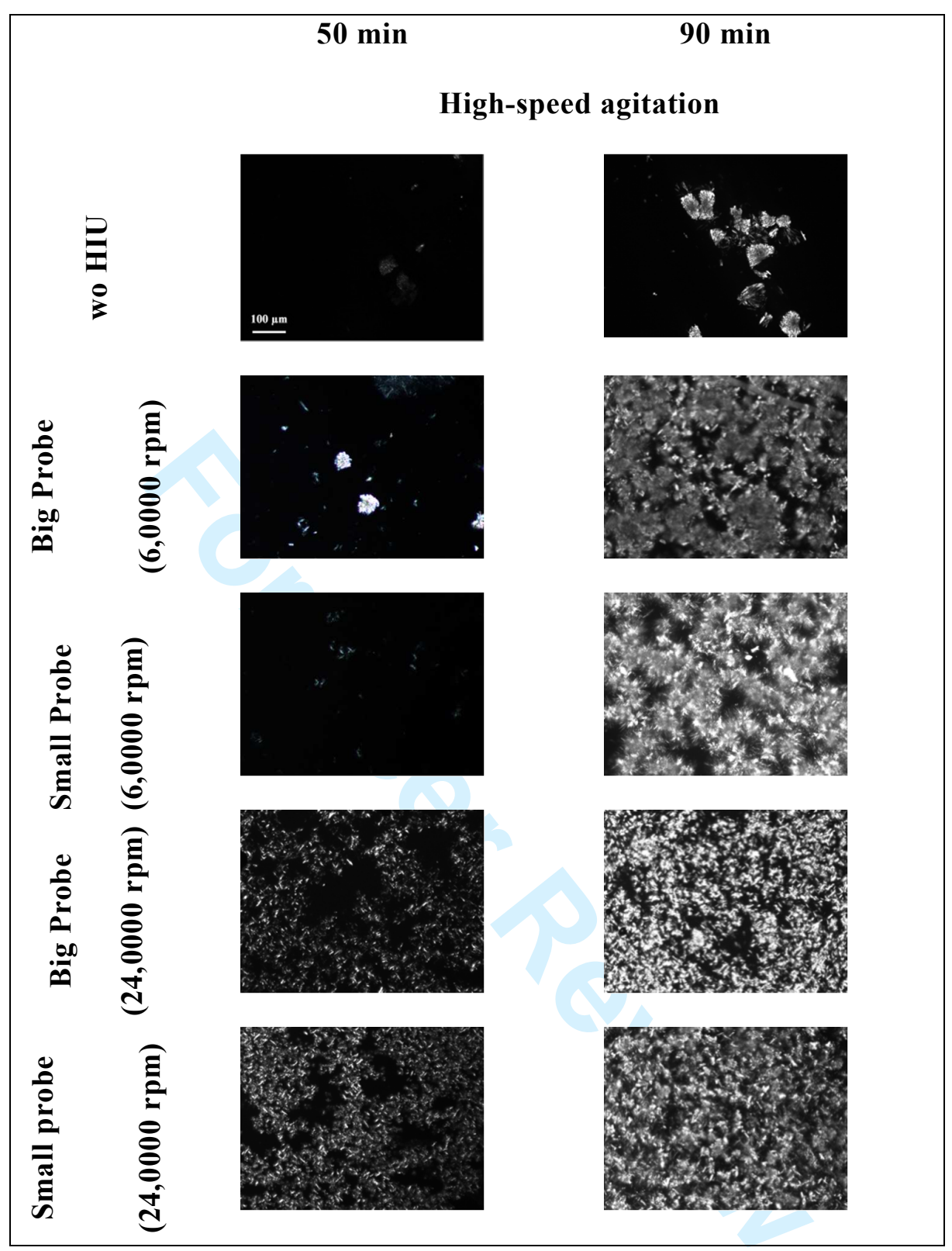

581

582 Figure 4. Polarized-light microscopy (PLM) images of IESBO crystallized at $44{ }^{\circ} \mathrm{C}$ without 583 and with high-speed agitation at 6,000 and $24,000 \mathrm{rpm}$. White bar in the first picture 584 represents $100 \mu \mathrm{m}$. 
$20 \mathrm{kHz}$
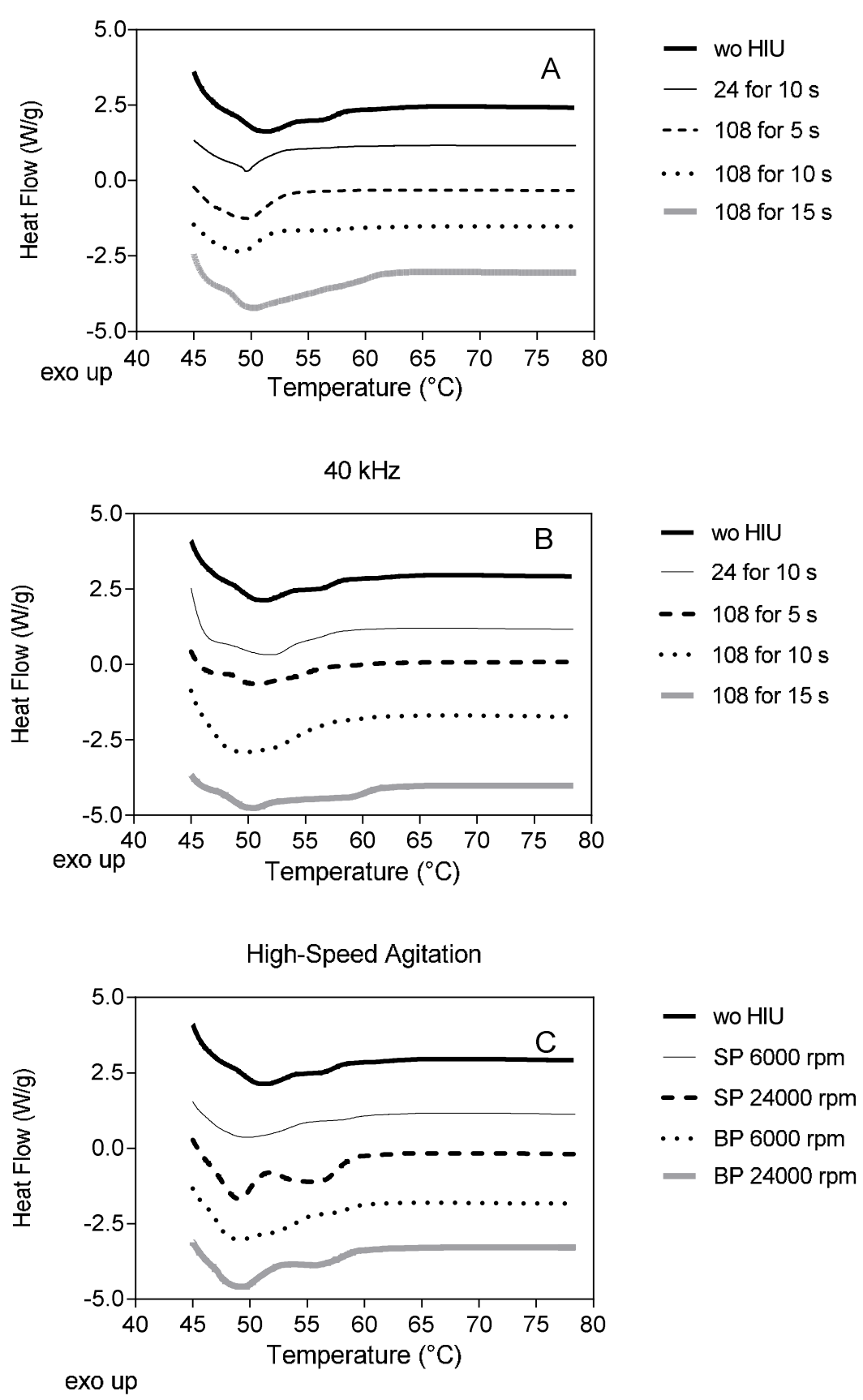

599 Figure 5. DSC melting profiles of IESBO crystallized for 90 min without and with HIU 600 using $20 \mathrm{kHz}$ (Figure 5A) and $40 \mathrm{kHz}$ (Figure 5B) of frequency. Melting profiles of samples 601 crystallized using high-speed Agitation are shown in Figure 5C. 


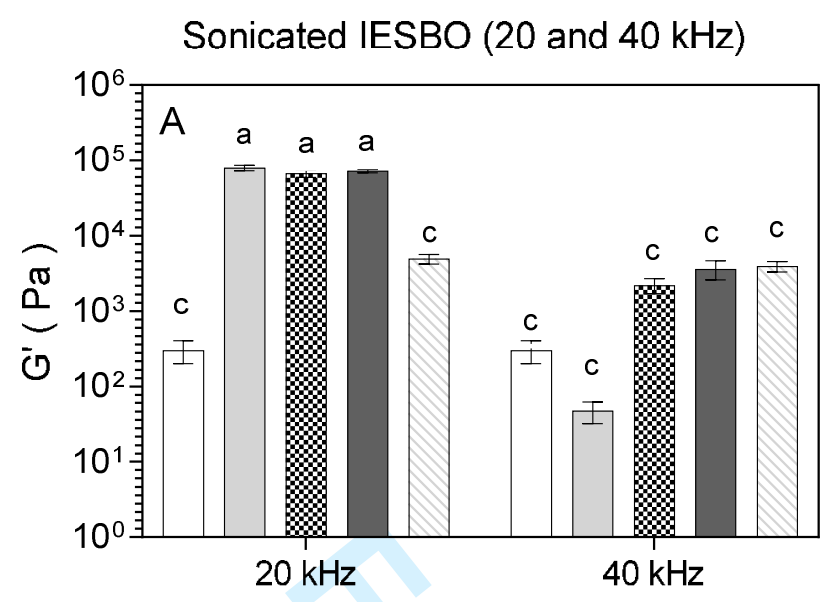

$$
\begin{aligned}
& \square \text { Wo HIU } \\
& \square \quad 24 \mu \mathrm{m} \text { for } 10 \mathrm{~s} \\
& 108 \mu \mathrm{m} \text { for } 5 \mathrm{~s} \\
& \square 108 \mu \mathrm{m} \text { for } 10 \mathrm{~s} \\
& \square 108 \mu \mathrm{m} \text { for } 15 \mathrm{~s}
\end{aligned}
$$

High-Speed Agitation

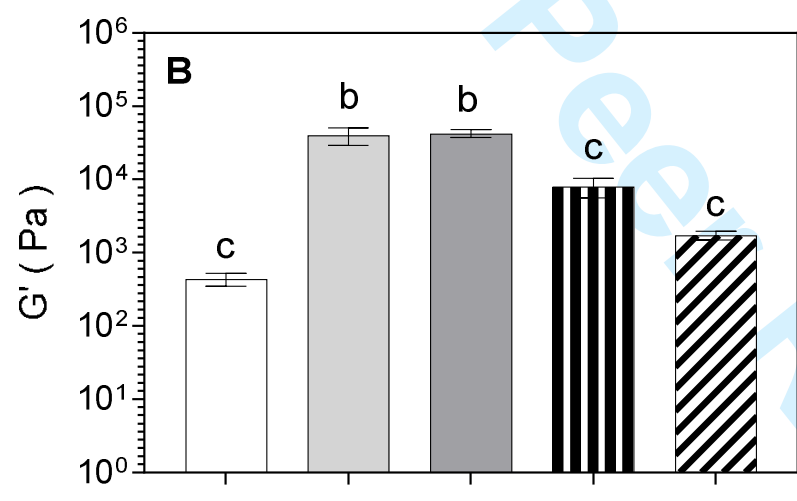

$$
\begin{array}{ll}
\square & \text { wo hiu } \\
\square \quad \text { Big Probe }(24,000 \mathrm{rpm}) \\
\square \quad \text { Small Probe }(24,000 \mathrm{rpm}) \\
\text { II } \quad \text { Big Probe }(6,000 \mathrm{rpm}) \\
\square \quad \text { Small Probe }(6,000 \mathrm{rpm})
\end{array}
$$

603

605 Figure 6. Elastic modulus (G') of IESBO crystallized for 90 min without and with HIU using 60620 and $40 \mathrm{kHz}$ frequency (Figure 6A) and high-speed agitation (Figure 6B) (Mean $\pm \mathrm{SEM}$ ).

607 Data with different letters are statistically different $(\alpha=0.05)$ 